\title{
Students' Conceptual Change in Electricity
}

\author{
Rimba Hamid \\ School of Postgraduate Studies UPI \\ Bandung, Indonesia \\ e-mail:rimbahamid@gmail.com
}

\author{
Ari Widodo \\ Indonesia University of Education Bandung, Indonesia \\ e-mail:widodo@upi.edu
}

\author{
WahyuSopandi \\ Indonesia University of Education Bandung, Indonesia \\ e-mail:wsopandi@upi.edu
}

\begin{abstract}
The phenomenon that represent electricity concept can be used to explore students' electricity concepts. Students' conceptual change toward electricity concept is taught through facilitation process, both in static electricity and dynamic electricity. The subjects of this research were 25 students of Elementary School Fourth Grade. Data of research were obtained from written responses and interviews toward students related to electricity concept through the approach of CTS (Contextual Teaching Sequence). Results of the research showed that if the concept is more abstract, the students tended to use their experiences as an idea basis in understanding electricity phenomenon, and in the process of concept thinking construction, students tended more to use assimilation process that tended to modify information in order for the initial scheme to be suitable compared to the accommodation process to replace the initial scheme in achieving their thinking balance, and in general the development of students' concept about electricity was highly influenced by the analogy toward their daily life experiences. With the CTS approach, there are still students misconceptions at the end of the lesson, but the involvement of student thinking is more optimal, and the number of students with an understanding of the concept of static electricity is more scientific as much as $\mathbf{5 2 \%}$ and the concept of power as much as $64 \%$, but on the electrical circuit and the electrical conductor and insulator relatively smaller percentage.
\end{abstract}

\section{Keywords-electricity; phenomenon; conceptual change}

\section{INTRODUCTION}

Everyday we come across physics in various fields, and in different ways. This gives us a general idea about some of the concepts in physics. However, sometimes, these concepts, which have developed in line with our past lives, do not match scientific facts. Those lives that do not overlap with scientific facts lead to misconceptions [1].

Research on students' and teachers' conceptions and their roles in teaching and learning science has become one of the most important domains of science education research on teaching and learning during the past three decades. Findings from many studies over the past three decades show that students do not come into science instruction without any preinstructional knowledge or beliefs about the phenomena and concepts to be taught. Rather, students already hold deeply rooted conceptions and ideas that are not in harmony with the science views or are even in stark contrast to them. It is noteworthy that there are still a remarkable number of studies on students' learning in science that primarily investigate such students' conceptions on the content level. Since the middle of the 1980s investigations of students' conceptions at metalevels, namely conceptions of the nature of science and views of learning (i.e., meta-cognitive conceptions) also have been given considerable attention. Research shows that students' conceptions here are also rather limited and naïve [2].

An example of misconception most frequently experienced by students about electricity is that when they are faced with the case "if a ruler that has been rubbed with paper is then put near small pieces of paper, the pieces of paper will be attracted" and this phenomenon is considered as amagnetism phenomenon while it is a static electricity phenomenon, and then some students also assume that all metals could be attracted by magnet and that power of magnet is the same in all of their parts. Therefore, the occurrence of early concept variations owned by students can be caused not only by abstract concept but also by other factors such as the students' diversed experiences related to electricity and magnet.

This condition should become a basis for teachers to have an intervention for a science learning process that could facilitate sufficient room to explore and assess the development of concept understood by students, from what they think about something concerning that concept before learning, how the process conceptual change occurred at every particular level, by making formative assessment toward the increase of students' concept understanding progress based on learning progression (LP)

One of the most important implications of conceptual change in education is that teaching for understanding cannot be achieved without a diagnosis toward students' early understanding about knowledge contents. Teachers have to realize the progress that has been made by science education community and have to learn to combine various diagnoses into learning technique and evaluation. The progress has to be given emphasis on qualitative expression just like on quantitative expression of an understanding [3].

\section{A. Concept of Conceptual Change}

Recent development concerning the term conceptual change has been very rapid, from the time Thomas Kuhn (1962) introduced it as an indication that the meaning of concept contained in science theory changed when theory (paradigme) changed (Vosniadou et al., 2008) to the time when conceptual change was viewed as a learning theory, 
where conceptual change was an ongoing process where one's early understanding or belief was changed into a direction of adjustment that was closer to experiences obtained scientifically [4].

The first theory about conceptual change was proposed by Posner, et.al [5] and two kinds of conceptual change were explained in this theory by using Piaget's two terms: assimilation and accommodation. In the first one, the new concept is assimilated by the pre-conceptual structure and in the second one conceptual structure is accommodated if a student's existed concepts contradict with the newly learn concepts. [5] assert that accommodation depends on some conditions. These conditions are listed below:

- Dissatisfaction of students with the existed concept.

- Plausibility of new concept.

- Intelligibility of new concept.

- Fruitfulness of new concept.

Approach of conceptual change involving teachers to make an early alternative thinking frame which was explicit to design a teaching approach consisting of ideas that were not fully suitable with the existing concepts and therefore would promote disstisfaction. A new frame was introduced based on formal science that probably explained something in a deviant way than usual way. And even, this thing became clear that students' conceptual progress toward understanding and concept learning and principles of science after learning turned out to be limited [6].

\section{B. Implication of Conceptual Change in Learning}

The nature and process of conceptual change are very interesting issues for inter-disciplinary researchers related to the development of science understanding, student, and cognitive development. Although the issues and the method to understand them have different formulation, there was a long history in every discipline about early condition and final condition in deep conceptual change, like what happened to the nature and change of representation from Newton mechanics to relativity theory, or from the mere understanding about physical phenomenon to scientific understanding provided by physics, biology, or from the structure of a person's early representation to adult society's representation of all range of phenomenon, including other people, during a cognitive development process [7].

Comprehensive perspectives in conceptual change process and remedy learning need to simultaneously handle some important issues that included: 1) explaining how to remembering and forgetting affected path of understanding, including opportunity to recall ideas spontaneously; 2) explaining how an individual's development impacted on the path of old learning, including predicting how rapid or gradual the change, and evidence for similarity of ideas at a typical age; 3 ) explaining how students interacted with multi contexts in the same phenomenon, including explaining the origins of misconception, alternative conception, beliefs, and constructive ideas; 4) explaining how students connected with various kinds of explanations of scientific phenomena one another, including descriptive explanation, causality explanation, and explanation about something invisible or dynamic processes; and 5) explaining how students responded to instructional activities, including the learning that increased abilities to help and analyze ideas of somebody [8].

In line with the above-mentioned perspectives, as a summary written by [9] from the perspective about learning and constructing knowledge has been largely presented, and would continue evolving. Nevertheless, at this stage, some key attributes of constructive paradigms that seemed to have an acceptance and agreement among education researchers are: 1) knowledge is a unique structure for a person; 2) assimilation and interconnection of knowledge elements produce understanding for a person; 3) a person actively builds knowledge and makes understanding for himself/herself through his/her experiences and reflection toward the knowledge he/she owns; 4) process of constructing knowledge is usually with stages, increases, and has assimilative nature; and 5) change in understanding is interpreted in a particular form of early knowledge and understanding.

It is strongly associated with the conceptual change is misconcetion. The NRC (1997) suggests that to break down students' misconceptions, teachers must first identify those misconceptions, provide a forum for students to confront them, and then help students reconstruct and internalize their knowledge, based on scientific models [10].Difficulties in learning at school frequently seem to derive from tenacious misconceptions constructed in everyday interactions, which offer enough explanatory power in that context, and the elementary school teachers' role as science educator is crucial, because they are responsiblefor instruction in all the natural sciences during children's first 6 school years in Finland.Thus, teachers have to master basic knowledge in many scientific fields such as physics, chemistry, and biology [11].

\section{RESEARCH METHOD}

\section{A. Subject}

The research was done to 25students of SDN 01 Baruga, Kendari City. Learning was conducted by using the CTS (Contextual Teaching Sequences) approach [12].

\section{B. Method}

This research used a qualitative approach, which was an interpretation of students' conceptual change from the ideas that they wrote in responding to the phenomenon which was related to electricity. Qualitative method was used to describe about students' conceptual change in electricity concept learning, including identification of misconception on each electricity sub-concept.

\section{Data Collection and Analysis}

Data in the form of students thinking results written in their concept books were the main data elaborated with interviews toward students coming from a certain group of ideas or mental models.

Data analysis was conducted by identifying each characteristic of data group from mental model, intermediary model, to science model, and also the existing misconception in every electricity sub-concept taught based on the phenomenon observed by every student. 


\section{RESULTS AND DISCUSSION}

\section{A. Characteristics of Student's Mental Model about Electricity}

Findings of research related to students' understanding of electricity concept in scientific concept entirely from the phenomena demonstrated by teachers in exploration phase of early knowledge, and was observed directly by students, showed that in general students' mental model in understanding electricity concept became more rational in giving reasons from early ideas they presented, from subconcept of static electricity to sub-concept of electricity conductor and insulator. This indicated that the proportion of students having mental model with a basis of intuition underwent tendency of decrease, as shown in Figure 1. Besides, it was also seen that the difficult-to-understand concept (presented more scientifically) by students was static electricity concept, and then electric current concept. Meanwhile, electric circuit concept with serial and parallel battery arrangements, and electric conductor and insulator concept could be understood by the majority of students in a more scientific way because they saw many of such things in real life, and also contribution of previous learning, although the concept explanation was not yet whole.

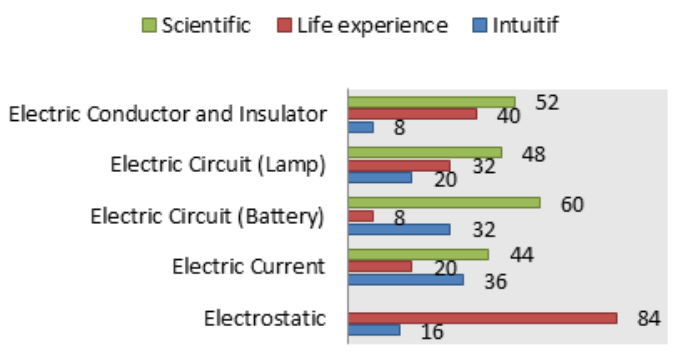

Fig. 1. Students percentage distribution based on mental model type about electricity

Based on the general findings shown in Fig 1, students' mental model profile about electricity could be explained as follows: 1) There was an increase of the total of students based on mental model type in seeing the electricity phenomenon, where the proportion of those with type I (intuition) was 22.4\%; type II (based on experience)was 36.8\%; and type III (science) was $40.8 \%$; 2).Related to the nature of science (ontology) of the phenomenon they saw, it was still very partial and procedural that focused more on the interpretation of the form of the object or material they saw. For example, in the concept of static electricity, it was more on ruler and paper; concept of electric current and circuit it was more on constructiong components; and concept of electric conductor and insulator it was more on material difference; nevertheless, there were some students having more scientific and constructive argument; 3) tendency of students's early understanding individually from four sub-concepts taughtdid notshow a relationship of sequential understanding (for example: student 14 having mental model type III (science) in electric current concept, and became type I (intuition) in electric conductor and insulator concept); and 4) The more abstract a concept was, the bigger the possibility for students to use life experience as a basis of argument (for examplein the static electricity concept, students thought that stickiness was caused by two main factors, namely because ofmagnetthat could attract magnetic objects andheatthat could stick an object, for example a fish scale would stick on the container of baking and rice crusts usually stuck on cooking container. Meanwhile, some students assuming that there was a friction force effect basically remained using again the basic intuition that friction could produce magnet effect and heat effect.

\section{B. Student's Conceptual Change about Electricity}

The following is the description of how students' conceptual change of all sub-concepts of about electricity matter, accompanied with an analysis about the misconception that was still found among students at the end of learning with the approach of CTS.

\section{TABLE I. STUDENTS' CONCEPTUAL CHANGE IN STATIC ELECTRICITY} CONCEPT

\begin{tabular}{|c|c|c|}
\hline Mental models & Intermediate models & Scientific models \\
\hline \multirow[t]{2}{*}{$\begin{array}{l}\text { Related to magnetic } \\
\text { properties }(48 \%)\end{array}$} & $\begin{array}{l}\text { Magnet stuck only on iron } \\
(32 \%)\end{array}$ & \multirow{4}{*}{$\begin{array}{l}\text { Friction caused the } \\
\text { movement of charges } \\
\text { or electricity } \\
(52 \%)\end{array}$} \\
\hline & Ruler has a stiky (12\%) & \\
\hline $\begin{array}{l}\text { Related to stickiness } \\
\text { force due to heat } \\
(36 \%)\end{array}$ & $\begin{array}{l}\text { There was a difference of } \\
\text { heat between the rubbed } \\
\text { object and the object heated } \\
\text { with fire }(24 \%)\end{array}$ & \\
\hline $\begin{array}{l}\text { Related to friction } \\
\text { force }(16 \%)\end{array}$ & $\begin{array}{l}\text { The rubbed ruler produced } \\
\text { magnetic force }(32 \%)\end{array}$ & \\
\hline $\begin{array}{l}\text { Misconception } \\
\text { identified at the end } \\
\text { of learning }\end{array}$ & $\begin{array}{l}\text { a. The rubbed object } \\
\text { force. }(28 \%) \\
\text { b. The attraction force } \\
\text { magnet }(4 \%) \\
\text { c. Electricity is made of h }\end{array}$ & $\begin{array}{l}\text { 11 produce attraction } \\
\text { duced is similar with } \\
(4 \%)\end{array}$ \\
\hline
\end{tabular}

Based on the data of Table I, it can be seen that the movement of students' conceptual change on static electricity from mental model to intermediary model did not yet fully change in that they were still on three early owned by the groups of students. Nevertheless, a group of students having the idea that pieces of paper attracted by ruler rubbed with wool cloth because related to friction froce, was relatively closer to scientific concept compared with two other groups that were related to magnetic properties and related to the stickiness of an object was because of heat effects. In intermediary model also appeared that in fact friction force concept understood by students was still related to magnetic force, because students were still isolated with the phenomenon they saw of magnet attracting iron.

TABLE II. STUDENT'S CONCEPTUAL CHANGE ABOUT ELECTRICAL CURRENT CONCEPT

\begin{tabular}{|c|c|c|}
\hline Mental models & Intermediate models & Scientific models \\
\hline $\begin{array}{l}\text { Battery changed into } \\
\text { electricity }(44 \%)\end{array}$ & $\begin{array}{l}\text { There was dynamo energy in } \\
\text { battery }(32 \%)\end{array}$ & \multirow{4}{*}{$\begin{array}{l}\text { Because there was } \\
\text { a battery that could } \\
\text { make electricity } \\
\text { function and a } \\
\text { cable through } \\
\text { which electric } \\
\text { current could flow } \\
\text { ( } 64 \% \text { of students) }\end{array}$} \\
\hline $\begin{array}{l}\text { Electric current that } \\
\text { spread }(32 \%)\end{array}$ & $\begin{array}{l}\text { There was a battery that } \\
\text { added electricity }\end{array}$ & \\
\hline $\begin{array}{l}\text { Electricity } \\
\text { connected to switch } \\
(14 \%)\end{array}$ & $\begin{array}{l}\text { The cable connecting to light } \\
\text { had electricity too }(64 \%)\end{array}$ & \\
\hline $\begin{array}{l}\text { Cable } \\
\text { electricity to light } \\
(4 \%)\end{array}$ & $\begin{array}{l}\text { Because cable was put near } \\
\text { battery }(4 \%)\end{array}$ & \\
\hline
\end{tabular}




\begin{tabular}{|l|l|l|}
\hline \multicolumn{1}{|c|}{ Mental models } & \multicolumn{1}{|c|}{ Intermediate models } & Scientific models \\
\hline $\begin{array}{l}\text { Misconception } \\
\text { identified at the end } \\
\text { of learning }\end{array}$ & $\begin{array}{l}\text { The presence of energy and dynamo in battery } \\
(16 \%) \\
\text { Because there was a switch (as if the switch could } \\
\text { contribute electric energy, because light on-off } \\
\text { depended on switch on-off) (20\%) }\end{array}$ \\
\hline
\end{tabular}

Students' conceptual change about electric current was largely influenced by the form of electric circuit component, they did not yet have a whole concept unit about electric current and its movement. As the continuation of electric current concept (dynamic electricity) was an electric circuit, and students' thinking profile about that concept is shown in Table III.

TABLE III. STUDENTS' CONCEPTUAL CHANGE IN ELECTRIC CIRCUIT CONCEPT

\begin{tabular}{|c|c|c|c|}
\hline \multicolumn{2}{|l|}{ Mental models } & Intermediate models & $\begin{array}{l}\text { Scientific } \\
\text { models }\end{array}$ \\
\hline \multirow{2}{*}{\multicolumn{2}{|c|}{$\begin{array}{l}\text { Position of battery } \\
\text { determined light } \\
\text { brightness }(60 \%)\end{array}$}} & $\begin{array}{l}\text { There was a difference of } \\
\text { parallel and serial } \\
\text { electrical current paths } \\
(24 \%)\end{array}$ & \multirow{6}{*}{$\begin{array}{l}\text { Difference of } \\
\text { electric circuits in } \\
\text { the parallel and } \\
\text { serial forms } \\
\text { caused the } \\
\text { brightness of } \\
\text { light (difference } \\
\text { of battery } \\
\text { arrangement and } \\
\text { light } \\
\text { arrangement) } \\
\text { (28\% of students) }\end{array}$} \\
\hline & & $\begin{array}{c}\text { Battery charges were } \\
\text { different }(20 \%)\end{array}$ & \\
\hline \multicolumn{2}{|l|}{$\begin{array}{c}\text { Power of wattage and } \\
\text { lifetime of battery }(32 \%)\end{array}$} & $\begin{array}{c}\text { Voltages of batteries } \\
\text { arranged parallelly and } \\
\text { serially were different } \\
(40 \%)\end{array}$ & \\
\hline \multirow{3}{*}{\multicolumn{2}{|c|}{$\begin{array}{c}\text { Parallel current was } \\
\text { winding, while serial } \\
\text { current was not (there was } \\
\text { a difference of path } \\
\text { length) }(8 \%)\end{array}$}} & $\begin{array}{l}\text { There was a difference of } \\
\text { the number of switches } \\
(4 \%)\end{array}$ & \\
\hline & & $\begin{array}{l}\text { Difference of battery } \\
\text { position and electric } \\
\text { current }(8 \%) \\
\end{array}$ & \\
\hline & & $\begin{array}{l}\text { Difference of power and } \\
\text { speed of electric currents } \\
(4 \%)\end{array}$ & \\
\hline $\begin{array}{c}\text { Misconception } \\
\text { identified at the end } \\
\text { of learning }\end{array}$ & \multicolumn{3}{|c|}{$\begin{array}{l}\text { a. There were serial lights and parallel lights } \\
\text { (students thought that type of light caused } \\
\text { brightness difference) }(60 \%) \\
\text { b. Winding cable circuit caused current to be slow, } \\
\text { so the light was dim }(12 \%)\end{array}$} \\
\hline
\end{tabular}

Results of analysis toward the data in Table III showed that there were two model concepts between the concept related to the difference of parallel and serial electric current paths and the concept related to the difference of electric power and current, or it could be said that some students viewed that students' concept about light brightness and dimness in a circuit was more on the physical things of the circuit that they saw with an interpretation that had analogy in their daily life.

TABLE IV. STUDENTS' CONCEPTUAL CHANGE ON CONCEPT OF ELECTRICAL CONDUCTOR AND INSULATOR

\begin{tabular}{|c|c|c|}
\hline Mental models & $\begin{array}{c}\text { Intermediate models } \\
\text { (case of carbon) }\end{array}$ & $\begin{array}{c}\text { Scientific } \\
\text { models }\end{array}$ \\
\hline $\begin{array}{c}\text { Electric conducting force } \\
\text { of an object depended on } \\
\text { the ability to conduct heat } \\
(40 \%)\end{array}$ & $\begin{array}{c}\text { Electric current could flow } \\
\text { everywhere except in plastic } \\
(4 \%)\end{array}$ & \\
& $\begin{array}{c}\text { Iron as a good } \\
\text { electricity } \\
\text { conductor } \\
\text { (32\% of } \\
\text { students) }\end{array}$ \\
\cline { 2 - 2 } $\begin{array}{c}\text { Metal had electrical } \\
\text { current/capable of }\end{array}$ & $\begin{array}{c}\text { When manufactured, it } \\
\text { largely touched metal }\end{array}$ & \\
\hline
\end{tabular}

TABLE IV. Cont'

\begin{tabular}{|c|c|c|c|}
\hline \multicolumn{2}{|l|}{ Mental models } & $\begin{array}{l}\text { Intermediate models } \\
\text { (case of carbon) }\end{array}$ & $\begin{array}{c}\text { Scientific } \\
\text { models }\end{array}$ \\
\hline \multicolumn{2}{|c|}{$\begin{array}{c}\text { conducting electricity } \\
(28 \%)\end{array}$} & $\begin{array}{c}\text { Had heat that could conduct } \\
\text { electricity }(8 \%)\end{array}$ & \\
\hline \multicolumn{2}{|c|}{$\begin{array}{l}\text { Plastic could not conduct } \\
\text { electricity because it was } \\
\text { not made of metal }(24 \%)\end{array}$} & $\begin{array}{l}\text { Tip of pencil could conduct } \\
\text { electricity because it was } \\
\text { made of carbonate acid, and } \\
\text { acid could conduct } \\
\text { electricity }(4 \%)\end{array}$ & \\
\hline \multirow{2}{*}{\multicolumn{2}{|c|}{$\begin{array}{l}\text { Metal connection had } \\
\text { strong energy, while } \\
\text { plastic did not }(4 \%)\end{array}$}} & $\begin{array}{l}\text { Due to the presence of } \\
\text { electric current,heat and } \\
\text { magnetic force }(8 \%)\end{array}$ & \\
\hline & & $\begin{array}{l}\text { Carbon and metal ways of } \\
\text { conducting were the same } \\
(4 \%)\end{array}$ & \\
\hline \multirow{2}{*}{\multicolumn{2}{|c|}{$\begin{array}{l}\text { Metal had very strong } \\
\text { magnet, while plastic had } \\
\text { slipper structure }(4 \%)\end{array}$}} & $\begin{array}{l}\text { There was carbohydrate that } \\
\text { connected }(4 \%)\end{array}$ & \\
\hline & & $\begin{array}{l}\text { Tip of pencil was made of } \\
\text { metal remains }(36 \%)\end{array}$ & \\
\hline $\begin{array}{c}\text { Misconception } \\
\text { identified at the end } \\
\text { of learning }\end{array}$ & $\begin{array}{l}\text { a. } \\
\text { b. } \\
\text { c. } \\
\text { d. }\end{array}$ & $\begin{array}{l}\text { Students equated electric } \\
\text { conductor, and objects that cou } \\
\text { magnet (such as iron) }(32 \%) \\
\text { Electric conductor was related to } \\
(8 \%) \\
\text { Plastic was electric insulator be } \\
\text { conduct heat } \\
\text { Iron is hot material }(28 \%)\end{array}$ & $\begin{array}{l}\text { iductor, heat } \\
\text { pe attracted by } \\
\text { agnetic current } \\
\text { se it could not }\end{array}$ \\
\hline
\end{tabular}

The dominant thing in the concept of electric conductor and insulator are the occurence of students' misconception who in majority equated electric conductor, heat conductor, and objects that could be attracted by magnet (such as iron), so there was an assumption that plastic had electric insulator properties because it could not attract magnet (there was no magnetic attraction) although the number was not big, yet this thing remain part of the thing that had to be noted by teachers in order to enable them to be facilitated toward a more scientific concept.

The results of this study showed that students who are the subject of this study came to the classroom actually have had prior knowledge about electricity, although it appears that there are only intuitive and analogous to daily experiences and some of them have a preliminary understanding more scientific as results of reading and watch, although the level into his reasoning is still very limited, and sometimes what he wrote different from that he understood and lead to misconceptions.

Misconceptions students have related to the concept of electric, both electrostatic and electro dynamic turned out to be quite diverse, ranging from electricity made from the heat, the switch has electrical energy, a series of cables snaking cause the flow to be slow, so that the light is dim, until the student difficulties distinguish between conductors of heat and electric conductor, and the students still assume that the electric insulating material is not a deliver electricity because they do not have a magnetic attraction.

In line with research conducted by [13] that the misconceptions related to "the consumptions related to current", "currents come from both terminals of the battery and they have the same intensity", "usage of voltage-currentenergy in place of each other", "no bulb lights of when the switch is off" and "bulbs connected in parallel give better light 
than those connected in series" are not seen in the post-test. Those misconceptions of "as the battery number increases the brightness of the bulb also increases", "a change made before the bulb effects the brightness of the bulb in a serial circuit" and "bulbs in series are brighter" are mentioned by small number of the students but the frequency of the misconception of "batteries are constant sources of current" increased compared to the pre-test.

Besides the things explained previously, about students' basic idea as a mental model and their conceptual change, it turned out that the students that became subjects in this research just for the first time learned about electricity concept, yet some of them had had early scientific knowledge although it was not yet complete and was sometimes less consistent. Therefore, with more contextual processes in the learning processes using suitable approach it was hoped to help students in understanding more scientific electricity concept.

The closeness of students' mental model on scientific concept was more on general concept that had been known by students, and the conceptual change process in intermediary model was more in the process that tended to keep their concept early scheme, by making statements that were only justification of the idea that they believed. This thing could be known when the students assumed that ruler had magnetic force in attracting pieces of paper, also when magnet was put nearby and the magnet could not attract the paper, students then had a new idea that "ruler and magnet have different attraction powers". In other study [14] show that conceptual change texts and web-assisted conceptual change texts can be used for eliminating the students' conceptual errors, even if they don't have a success of $100 \%$.

\section{CONCLUSION}

The conclusion of the whole discussions that have been presented was that there were various basic ideas and students' ways of building the concepts related to the learning of electricity, where in general students' concept building was largely influenced by analogy toward their daily life experiences. This reality certainly became a basis for teachers in selecting the approach that enabled students to construct their thoughts more easily, especially about the concept of electricity.

\section{References}

[1] Ozkan, G. and Selcuk, G. S. 2012. How Effective is "Conceptual Change Approach" In Teaching Physics?. Journal of Educational and Instructional Studies In The World. 2 (2): 182-190.

[2] Duit, Reinders and Treagust, David. 2003. Conceptual Change: A Powerful Framework for Improving ScienceTeaching and Learning. International Journal of Science Education. 25 (6): pp. 671-688

[3] Carey, S. (2010). Science education as conceptual change.Journal of Applied Developmental Psychology 21(1): 13-19. New York: Elsevier Science Inc.

[4] Vosniadou, S., Vamvakoussi, X., and Skopeliti, I. (2008). The framework theory approach to the problem of conceptual change. In: S. Vosniadou (Ed), International handbook of research on conceptual change (pp. 3-34). New York: Routledge.

[5] Posner, G.J., Strike, K.A., Hewson, P.W. \&Gertzog, W.A. (1982). Accommodation of a scientific conception: Towarda theory of conceptual change. Science Education, 66, 211-227.
[6] Duit, R., Treagust, D. F., Widodo, A. (2008). Teaching science for conceptual change: Theory and practice. In: S. Vosniadou (Ed), International handbook of research on conceptual change (pp. 629646). New York: Routledge

[7] Nersessian, N. J. (2008). Model mentaling conceptual change: Theory and practice. In: S. Vosniadou (Ed), International handbook of research on conceptual change (pp. 391-416). New York: Routledge

[8] Linn, M. C.. (2008). Teaching for conceptual change: Distinguish or Extinguish Ideas. In: S. Vosniadou (Ed), International handbook of research on conceptual change (pp. 694-722). New York: Routledge.

[9] Anderson, D. (1999). The development of scince concepts emergent from science museum and post-visit activity experiences: Student's construction of knowledge. A Thesis of the degree of Doctor of Philosophy in the Centre for mathematics and Science Education of the Queensland University of Technology.

[10] Gooding, J. and Metz, B. 2011. From Misconception to Conceptual Change: Tips for identifying and overcoming students' misconceptions. The Science Tonline] static.nsta.org/files/tst1104_34.pdf

[11] Ahopelto, I., Mikkilä-Erdmann, M., Anto, E., \&Penttinen, M. (2011). Future elementary school teachers' conceptual change concerning photosynthesis.Scandinavian Journal of Educational Research, 55(5), 503-515.

[12] Duit, R., Widodo, A., and Wodzinski, C. T. (2007). Conceptual change ideas: Teacher's views and their instructional practice. In: S. Vosniadou, A. Baltas, X. Vamvakoussi (Eds), Re-framing the conceptual change approach in learning and instruction (pp. 197-217). Amsterdam: Elsevier Ltd

[13] Kucukuzer and Kocakulah. (2008). Effect of Simple Electric Circuits Theaching and Conceptual Change in Grade 9 Physic Course.Journal of Turkish Science Education. 5 (1): pp. 59-74

[14] Tas, E., Gulen, S., Oner, Z., and Ozyurek, C. (2015). The effects of classic and web-designed conceptual change texts on the subject of water chemistry.International Electronic Journal of Elementary Education. 7(2): 263-280. 